\title{
Economic and energy efficiency of the solid biofuels produced from digested pulp
}

\author{
Wojciech Czekała ${ }^{1}$, Sylwia Bartnikowska ${ }^{1}$, Aleksandra Lewicka ${ }^{2}$, Artur Bugała ${ }^{3}$, Zbyszek Zbytek $^{4}$, Andrzej Lewicki ${ }^{1}$. \\ ${ }^{1}$ Institute of Biosystems Engineering, Poznan University of Life Sciences, ul. Wojska Polskiego 28, 60-637 Poznan, Poland \\ ${ }^{2}$ Institute of Environmental Engineering, Poznan University of Technology, Piotrowo 3a, 60-965 Poznan, Poland \\ ${ }^{3}$ Institute of Electrical Engineering and Electronics, Poznan University of Technology, ul. Piotrowo 3a, 60-965 Poland \\ ${ }^{4}$ Industrial Institute of Agricultural Engineering, ul. Starolecka 31 60-963 Poznan, Poland
}

\begin{abstract}
One of the methods of renewable energy production is biogas plant. Products of anaerobic digestion are biogas and residual material called digested pulp or digestate. This material is commonly used as a fertilizer. One of a new possibility of digested pulp management is solid biofuels production after separation. This paper presents the calculation of cost for production of briquettes from digested pulp. The performed economic analysis proves that the production of briquettes from digested solid fraction (DSF) can be profitable and provide additional income for the biogas

plant.
\end{abstract}

\section{Introduction}

Nowadays rational waste management is one of the most important environmental issues. The reason of this situation is an upward trend of the generated waste. On the other hand it is a consequence of the increase of human population and higher standards of living, especially in developed countries. Among the waste materials, the specific group includes organic waste and residues, which are characterized by high content of moisture and organic matter. This group includes animal faeces [1], sewage sludge [2-4], residues from the forestry sector [5] and agri-food waste [6].

Due to the properties of above mentioned waste, the most suitable methods of management are biological processes, in particular composting [7-9]. Composting carried out under proper conditions allow to obtain a valuable organic fertilizer. Another advantage of composting is the reduction of weight and volume of waste $[10,11]$. Except from composting more and more attention is paid to use organic waste as substrate in biogas plants $[12,13]$. In those installations anaerobic microorganisms can degrade organic matter to the final product i.e. biogas [14]. Biogas is a mixture of various gases and the most important one, in terms of energy, is methane [15].

The by-product of this process is digested pulp which is removed each day from reactor chambers. Due to chemical composition digested pulp is generally used in agriculture for fertilizing purposes [16,17]. However, digestate which has specific properties can be processed into other products. For example, the solid fraction after the separation - referred to as digested solid fraction (DSF) - is a suitable material for composting or producing solid biofuels [18-20]. Taking into account relatively low public support for renewable energy sources in Poland, the proper management of digested pulp can have a direct significant impact on improvement of the economic balance of the operating biogas plants.

\section{Aim and the range of research}

The aim of the study was to analyze the economical aspect of production of briquettes, prepared from solid fraction of digested pulp obtained from a selected agricultural biogas plant. The scope of research included the selection of the appropriate elements of the installation and energy analysis of produced solid fuel.

\section{Materials and methods of research}

The object of the study was digested pulp from one of the most modern agricultural biogas plant in Poland. Power of discussed installation is about $1 \mathrm{MW}$ of electricity and $1 \mathrm{MW}$ of thermal energy, at daily production of biogas over $13000 \mathrm{~m}^{3}$.

In the analyzed plant the daily production of DSF was about $10 \mathrm{Mg}$ with a dry matter content of about $25 \%$. According to the Polish legal norms, the use of waste for energy is classified as the recovery method R1 "principal use as a fuel or other means to generate energy" [21]. The analysis of the physical and chemical properties of digested pulp and prepared solid biofuel taken directly from the production line of the biogas plant (fig. 1) was performed in the Laboratory of Ecotechnology at the Institute of Biosystems Engineering at Poznan University of Life Sciences. According to the 
norm [22] the dry matter content was determined and following the standard [23] the dry matter of briquette from digested pulp according to the norm [24] the heat of combustion and calorific value of the tested briquettes was determined using the calorimeter method. Measurement of the heat of combustion was based on complete combustion of the substrate sample placed in a calorimeter bomb immersed in water. Measurement was performed with clean oxygen conditions.

Based on the obtained results the available information about the installation and using the presented assumptions, the economic analysis of the production of briquettes from the solid fraction of digestate was performed.

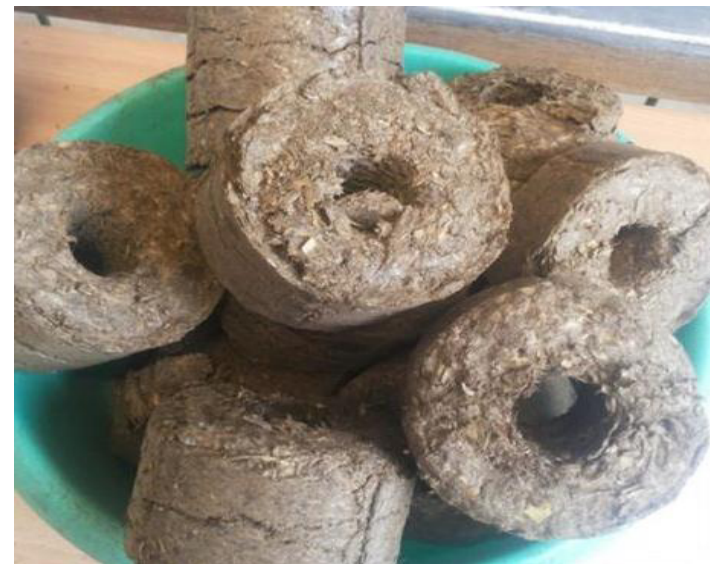

Figure 1. Briquettes from the solid fraction of digestate

\section{Discussion of results}

\subsection{The properties of the tested material}

The research results show that the dry matter of the produced briquettes was $87 \%$, while the dry organic matter was $88.64 \%$. In turn, the heat of combustion of the

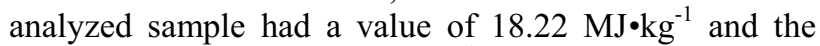

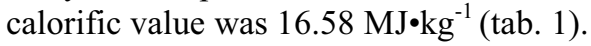

Table 1. The parameters of the tested material

\begin{tabular}{|c|c|}
\hline Substrate & $\begin{array}{c}\text { Briquette from } \\
\text { digestate }\end{array}$ \\
\hline Dry matter [\%] & 87.00 \\
\hline Organic dry matter [\%] & 88.64 \\
\hline $\begin{array}{c}\text { Heat of combustion } \\
{\left[\mathrm{MJ} \cdot \mathrm{kg}^{-1}\right]}\end{array}$ & 18.22 \\
\hline Heating value $\left[\mathrm{MJ} \cdot \mathrm{kg}^{-1}\right]$ & 16.58 \\
\hline
\end{tabular}

\subsection{Economic analysis}

The unit price of briquettes production from DSF is determined based on many factors. The most important is the cost of the substrate which is often times is high. In this study the cost of substrate was gained for free using the digestate, i.e. by-product of the fermentation process. Other elements of the balance were the following costs: depreciation of equipment, the cost of electricity, salary for employees, the cost of repair and maintenance of machines, cost of building the hall dedicated to drying and the production of briquettes as well. The balance sheet also included the costs of bags used for briquettes packing. Currency exchange rate was $1 €=4.2249$ PLN

\subsection{Depreciation costs}

In this project the separator of AgriKomp company was used. The obtained DSF was transported to the belt dryer (PSD 500 Airtechno) that used the energy from generated in the biogas plant. To produce biofuel, the briquetting

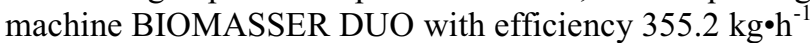
(ASKET) was used. In the calculation, the depreciation cost of the machine included the total cost of the machine, years of work and the amount of substrate processed per year by the device. The analysis assumes that the operating time for all our used machinery was 10 years. In order to estimate the depreciation costs of briquetting machine, its efficiency $\left(355.2 \mathrm{~kg}^{\circ} \mathrm{h}^{-1}\right)$, was taken into account. And it allowed to calculate the annual production of briquette. Concerning calculation of depreciation of the separator and the dryer, additional information about humidity of digestate solid fraction was required. This allowed to calculate that from one $\mathrm{Mg}$ of fresh DSF can be obtained $287 \mathrm{~kg}$ of briquettes. The total cost of depreciation of equipment used in the analysis is $12.81 € \cdot \mathrm{Mg}^{-1}$ (tab. 2). For dryer depreciation cost half of the total sum of machine has been adopted, because the device is also used for drying other substrates in the agricultural farm.

Table 2. The total cost of depreciation

\begin{tabular}{|c|c|c|c|}
\hline & Separator & $\begin{array}{c}\text { Dryer } \\
\text { belt }\end{array}$ & $\begin{array}{c}\text { Briquetting } \\
\text { machine }\end{array}$ \\
\hline $\begin{array}{c}\text { The price for a } \\
\text { machine }[€]\end{array}$ & 52072.24 & 69000 & 12966.98 \\
\hline $\begin{array}{c}\text { Amount of } \\
\text { briquettes } \\
{\left[€ \cdot \mathrm{Mg}^{-1}\right]}\end{array}$ & 1047.55 & 1047.55 & 1037.18 \\
\hline $\begin{array}{c}\text { The total cost } \\
\text { of } \\
\text { depreciation }\end{array}$ & $12.81 € \cdot \mathrm{Mg}^{-1}$ \\
\hline
\end{tabular}

\subsection{Electricity costs}

The cost of electricity is a ratio of the following components: hours needed to produce one $\mathrm{Mg}$ of briquettes, the current price of industrial electricity fixed by the distributor of the power grid and power consumption of the device. The industrial price of electricity from the ENEA power supplier and distributor was assumed to be $0.11 € \bullet \mathrm{kWh}$. The analysis assumed that the cost of electricity for the separator was $26,04 € \cdot \mathrm{Mg}^{-1}$. This listing also includes salary for an employee. On the other hand, energy costs for drying have zero value, because recovery heat on biogas plant is free. In case of briquetting machine, the energy input published on the 
producer website $\left(70 \mathrm{kWh} \cdot \mathrm{Mg}^{-1}\right)$ was used in calculations, along with other components of the ratio, i.e. time required to produce $1 \mathrm{Mg}$ of briquettes $-2.82 \mathrm{~h}$ and the price of electricity. The calculation showed that the total cost of electricity for briquetting machine was $7.46 € \bullet \mathrm{Mg}^{-}$ 1

\subsection{Costs of repairs and maintenance of machines}

The analysis assumes that the costs of repairs and maintenance of machines constitute $30 \%$ of the amortization cost for each device. Therefore, it has been proved that the total costs amounted to $2.86 € \cdot \mathrm{Mg}^{-1}$, and the structure was diverse (table 3 ). The largest share of the costs relating to repairs and maintenance $(52.1 \%)$ was in case of separator, on drying $(34.6 \%)$ and briquetting $(13.3 \%)$ consecutively.

Table 3. The structure of repair and maintenance cost of machines

\begin{tabular}{|c|c|}
\hline Device & $\boldsymbol{\epsilon} \cdot \mathbf{M g}^{\mathbf{- 1}}$ \\
\hline Separator & 1.49 \\
\hline Dryer belt & 0.99 \\
\hline Briquetting machine & 0.38 \\
\hline
\end{tabular}

\subsection{Salary for employees}

Calculating the salary costs for employees one-shift ( 8 hours) labour was assumed, with a rate of $3.55 € \cdot \mathrm{h}^{-1}$. Whereas taking into account that briquetting can be operated by one person, the cost was calculated as 10.01 $€ \cdot \mathrm{Mg}^{-1}$ (tab. 4). It is worth to highlight that the costs of separator servicing are included in the electricity costs.

Table 4. The salary for the employee briquetting

\begin{tabular}{|c|c|}
\hline Number of Employees [-] & 1 \\
\hline Number of work shift [-] & 1 \\
\hline $\begin{array}{c}\text { Number of hours per one shift [h] } \\
\text { Hourly rate [€/h] }\end{array}$ & 3.55 \\
\hline $\begin{array}{c}\text { Mg of briquettes } \\
\text { Number of hours which is need to produce } 1\end{array}$ & 2.82 \\
\hline $\begin{array}{c}\text { Salary for employee per 1 Mg of biofuel } \\
\text { [- }]\end{array}$ & 10.01 \\
\hline
\end{tabular}

\subsection{Additional costs}

The additional cost was related to the construction of 300 $\mathrm{m}^{2}$ hall intended for drying purposes and briquettes production. The cost of this construction was $66.365 €$. Calculated per $1 \mathrm{Mg}$ of briquette the obtained cost was $1.62 €$.The total balance sheet also included the cost of packing bags for briquettes. Assuming the price of 1,000 bags with a capacity of $15 \mathrm{~kg}$ at the level of $0.14 €$ it was calculated that the cost of the bags for $1 \mathrm{mg}$ briquettes was $6.94 €$.

Economic analysis shows that there are three main components of the costs for the analyzed case. The first group includes the costs associated with the exploitation of the separator which in total amounted to $32.50 €$ (Tab. $5)$. Within this group, the highest share $(80.1 \%)$ was assigned to the electricity associated with the concerns amortization and approx. $4.6 \%$ are the costs of repair and maintenance work.

Table 5. The unit costs for DSF briquettes

\begin{tabular}{|c|c|c|}
\hline \multicolumn{2}{|r|}{$1 \mathrm{Mg}$ DSF briquettes cost } & $€ \cdot \mathbf{M g}^{-1}$ \\
\hline \multicolumn{3}{|c|}{ DIGESTED SOLID FRACTION } \\
\hline 1. & Purchase of raw materials & 0 \\
\hline \multicolumn{3}{|c|}{ SEPARATOR } \\
\hline 2. & Depreciation of separator & 4.97 \\
\hline 3. & Electricity for separator & 26.04 \\
\hline 4. & Repair and maintenance of machinery & 1.49 \\
\hline & The total cost for the group - separation & 32.5 \\
\hline \multicolumn{3}{|c|}{ BELT DRIER } \\
\hline 5. & Depreciation of dryer & 6.159 \\
\hline 6. & Electricity for dryer & 0 \\
\hline 7. & Hall dedicated to drying & 1.62 \\
\hline 8. & Repair and maintenance of machinery & 0.99 \\
\hline & The total cost for the group - drying & 9.20 \\
\hline \multicolumn{3}{|c|}{ BRIQUETTING MACHINE } \\
\hline 9. & Depreciation of briquetting machine & 1.25 \\
\hline 10. & Electricity for briquetting machine & 7.46 \\
\hline 11. & Repair and maintenance of machinery & 0.38 \\
\hline 12. & Salary for employee & 10.00 \\
\hline 13. & Bags for packing briquettes & 6.94 \\
\hline & $\begin{array}{l}\text { The total cost for the group - } \\
\text { briquetting machine }\end{array}$ & 26.03 \\
\hline & $\begin{array}{l}\text { TOTAL COST OF } 1 \text { Mg DSF } \\
\text { BRICQUETTES PRODUCTION }\end{array}$ & 67.71 \\
\hline
\end{tabular}


The second component represents the expenses spent on the exploitation of the dryer, totally amounted to $9.20 €$. The largest share of the costs $(71.6 \%)$ was the dryer depreciation cost. The $17.6 \%$ of the costs was related to the construction of the hall, and $10.8 \%$ were the costs for repair and maintenance (tab. 5).

The last component was the costs associated with the exploitation of briquetting machine which accounted to $26.03 €$. Distribution of costs in this group was more diverse compared to the two previous ones (tab. 5). The largest costs $(38.4 \%)$ were related to the salary of employees and electric energy $(28.7 \%)$. In turn the smallest share $(1.5 \%)$ were the costs of repair, maintenance and amortization of the machine (4.8\%).

In the presented analysis, the cost of production of 1 $\mathrm{Mg}$ of briquettes from DSF was $67.73 €$ (Tab. 5). The $48.0 \%$ of this amount were the costs for the separator, $38.4 \%$ were related to the briquetting machine and $13.6 \%$ were drying costs.

\section{Summary and conclusions}

In the analyzed agricultural biogas plant the daily production of fresh DSF is $10 \mathrm{Mg}$. The digested pulp can be used by the R10 method - as organic fertilizer, by R3 for compost production, R1 - as a fuel [21], or by R1 using the digestate as a fuel.

The performed economic analysis proves that the production of briquettes from DSF can be profitable. The right argument is the low cost of production of $1 \mathrm{Mg}$ of briquette which is $67.71 €$ at the market price of solid biofuels ranging from $100 €$ to $170 €$ per $\mathrm{Mg}$. This means that the sale of briquettes can provide additional income for the biogas plant. Moreover, the production of briquettes allows the management of the DSF, which is perceived as a problematic by-product in the process of methane fermentation. Because the calorific value of DSF briquettes is similar to other ones, it determined the tested material an attractive biofuel.

\section{References}

1. W. Czekała, J. Dach, A. Ludwiczak, A. Przybylak, P. Boniecki, K. Koszela, M. Zaborowicz, K. Przybył, D. Wojcieszak. The use of image analysis to investigate $C: N$ ratio in the mixture of chicken manure and straw. Proc. SPIE. 9631, Seventh International Conference on Digital Image Processing (ICDIP 2015), 963117. (July 06, 2015) doi: 10.1117/12.2197041 (2015)

2. I. Białobrzewski, M. Mikš-Krajnik, J. Dach, M. Markowski., W. Czekała, K. Głuchowska. Model of the sewage sludge-straw composting process integrating different heat generation capacities of mesophilic and thermophilic microorganisms. Waste Management 43, 72-83. DOI:10.1016/j.wasman.2015.05.036 (2015)

3. K. Malińska, M. Zabochnicka-Świątek, J. Dach. Effects of biochar amendment on ammonia emission during composting of sewage sludge. Ecological Engineering 71, 474-478 (2014)
4. S. Kujawa, R.J. Tomczak, T. Kluza, J. Weres, P. Boniecki. A stand for the image acquisition of composted material based on the sewage sludge. 4th International Conference on Digital Image Processing. Kuala Lumpur (Malaysia), proceedings of SPIE, Vol. 8334, Article Number: 83341R, DOI: 10.1117/12.949899 (2012)

5. J. Starzyk, W. Czekała. The Influence of Admixtures Accelerating the Pine Bark Composting Process on Variation in the Bacteriological State of Composts. Archives of Environmental Protection 40, 4, 125-135, DOI: 10.2478/aep-2014-0044 (2014)

6. W. Czekała, K. Kozłowski, J. Dach, P. Boniecki, A. Lewicki, D. Janczak, K. Jóźwiakowski, T. Piechota. Energy Conversion from Biomass to Hydrogen and Methane. 4th International Conference on Materials Engineering for Advanced Technologies (ICMEAT) Location: London, ENGLAND Date: JUN 27-28, 2015 Pages: 654-657 (2015)

7. W. Czekała, K. Malińska, R. Cáceres, D. Janczak, J. Dach, A. Lewicki. Co-composting of poultry manure mixtures amended with biochar - The effect of biochar on temperature and C-CO2 emission. Bioresource Technology 200, 921-927 (2016)

8. K. Malińska, M. Zabochnicka-Świątek. Selection of bulking agents for composting of sewage sludge. Environment Protection Engineering 39, 2, 91-103 (2013) 9. A. Piotrowska-Cyplik, Ł. Chrzanowski, P. Cyplik, J. Dach, A. Olejnik, J. Staninska, J. Czarny, A. Lewicki, R. Marecik, J. Powierska-Czarny. Composting of oiled bleaching earth: Fatty acids degradation, phytotoxicity and mutagenicity changes. International Biodeterioration \& Biodegradation. Vol. 78, March 2013: 49-57 (2013)

10. A. Lewicki, J. Dach, P. Boniecki, W. Czekała, K. Witaszek. The Control of Air Humidity and Temperature in Relationship with a Biowaste Composting Process. Advanced Materials Research Vol. 909 pp 455-462. DOI 10.4028/www.scientific.net/AMR.909.455 (2014)

11. D. Janczak, M. Marciniak, A. Lewicki, W. Czekała, K. Witaszek, P.C. Rodríguez Carmona, M. Cieślik, J. Dach. Bioreactor Internet System for Experimental Data Monitoring and Measurement, Procedia Technology 8, 209 - 214 (2013)

12. Dach J., Koszela K., Boniecki P., Zaborowicz M., Lewicki A., Czekała W., Skwarcz J.,Wei Q. PiekarskaBoniecka H., Białobrzewski I. The use of neural modelling to estimate the methane production from slurry fermentation processes. Renewable and Sustainable Energy Reviews 56, 603-610. doi:10.1016/j.rser.2015.11.093 (2016)

13. A. Lewicki, J. Dach, D. Janczak, W. Czekala. The experimental macro photoreactor for microalgae production, Procedia Technology 8, 622-627 (2013)

14. A. Lewicki, P. Boniecki, J. Dach, D. Janczak, W. Czekała, Z. Zbytek, M. Cieślik. Neural Estimation of Biomethane Efficiency from Maize Silage, Maize Straw and Cattle Slurry. 4th International Conference on Materials Engineering for Advanced Technologies (ICMEAT) Location: London, ENGLAND Date: JUN 27-28, 2015. Pages: 649-653 (2015)

15. J. Dach, W. Czekała, P. Boniecki, A. Lewicki, T. Piechota. Specialised Internet Tool for Biogas Plant Modelling and Marked Analysing. Advanced Materials 
Research Vol. 909 pp 305-310. 7 pkt. DOI 10.4028/www.scientific.net/AMR.909.305 (2014)

16. D. Zirkler, A. Peters, M. Kaupenjohann. Elemental composition of biogas residues: Variability and alteration during anaerobic digestion. Biomass and bioenergy 67, 89-98; (2014)

17. H.I. Owamah, S.O. Dahunsi, U.S. Oranusi, M.I. Alfa. Fertilizer and sanitary quality of digestate biofertilizer from the co-digestion of food waste and human excreta. Waste Management 34, 747-752 (2014)

18. S. Pedrazzi, G. Allesina, T. Belló, C.A. Rinaldini, Tartarini P. Digestate as bio-fuel in domestic furnaces. Fuel Processing Technology 130, 172-178; Tambone F., Terruzzi L., Scaglia B., Adani F. 2015. Composting of the solid fraction of digestate derived from pig slurry: Biological processes and compost properties. Waste Management 35, 55-61 (2015)

19. M.A. Bustamante, J.A. Alburquerque, A.P. Restrepo, C. Fuente, C. Paredes, R. Moral, M.P. Bernal. Cocomposting of the solid fraction of anaerobic digestates, to obtain added-value materials for use in agriculture. Biomass and bioenergy 43, 26-35 (2012)

20. M. Kratzeisen, N. Starcevic, M. Martinov, C. Maurer, J. Müller. Applicability of biogas digestate as solid fuel. Fuel 89, 2544-2548 (2010)

21. Polish Act of 14 December 2012 on Waste

22. PN-75 C-04616/01 - Water and wastewater. Special research of sludge. Determination of water content, dry matter, organic matter and mineral substances in sewage sludge.

23. PN-Z-15011-3 :2001 - Compost from municipal solid waste. Determination of $\mathrm{pH}$, organic matter content, organic carbon, nitrogen, phosphorus and potassium.

24. PN-81/G-04513 -"Solid fuels. Determination of gross calorifie value and calculation of net calorific value". 